\title{
TNP1 wt Allele
}

National Cancer Institute

\section{Source}

National Cancer Institute. TNP1 wt Allele. NCI Thesaurus. Code C106293.

Human TNP1 wild-type allele is located within 2q35-q36 and is approximately $1 \mathrm{~kb}$ in length. This allele, which encodes spermatid nuclear transition protein 1 , plays a role in sperm morphology. 